\title{
Features of Predisposition to Eating Disorder among Adolescents who are on Diet outside the Prescription of a Doctor
}

\section{Особливості схильності до розладів харчової поведінки серед підлітків, які дотримуються дієти поза призначенням лікаря}

Oleksandr Avramchuk

Ph.D. in Psychology, Assistant Professor

\author{
Олександр Аврамчук \\ кандидат психологічних \\ наук, доцент
}

E-mail: avramchuk.md@ucu.edu.ua orcid.org/0000-0001-8512-7817

Researcher ID: A-7595-2019

Clinical Psychology

Department, Ukrainian

Catholic University, Lviv,

Ukraine

17, Il. Svientsitskoho str.,

Lviv, Ukraine, 79000

Oksana Kruts

MSc. in Psychology,

Private Psychologist
Кафедра клінічної психологї, Український католицький університет, лм. Львів,

Україна

вул. Іл. Свєнціцького, 17, м. Львів, 79000

Оксана Круц магістр психології, приватний психолог

E-mail: havrysyshyn@gmail.com orcid.org/0000-0002-0160-4610

Researcher ID: A-8531-2019

Psychological studio «Sense», Lviv, Ukraine

9, Lemkivska str., Lviv, 79000
Психологічна студія «Сенс», м. Львів, Украӥна вул. Лемківська, 9, м. Львів, 79000

Original manuscript received December 05, 2018

Revised manuscript accepted January 16, 2019 
ABSTRACT

In the article, the impact of "diet» is considered that is used by adolescents outside medical prescription for controlling their weight, emotional state and maintaining self-esteem.

The researches for the last ten years are analyzed, the psychosocial factors of predisposition to the formation of disorders of eating behavior among adolescents are explained and described. In order to solve the problems we have formed a sample of respondents: adolescents aged 12-14 years from Ternopil and Lviv schools. At the beginning of the study, 347 questionnaires were received, 88 of them were included in the experimental group. Participants were offered diagnostic materials, in particular: The Eating Disorder Impairment Questionnaire and the Hospital Anxiety and Depression Scale screening scale.

According to the results of work we described five aspects of predisposition to eating disorder among adolescents. Key among of them is body dissatisfaction and low self-esteem. It is established that low self-esteem intensifies fixation on the problem areas of the body by increasing the desire for harmony, and the unproductive use of rigid diets or restrictions in the amount of food gives a sense of control over emotions and thoughts. At the same time, it is indicated that the anxiety that is felt in this regard affects the propensity to interpersonal alienation. It is concluded that depression and uncontrolled overeating might act as independent triggers for the distress and modifying factors supporting the development of eating disorders are the fear of ripening and perfectionism.

The materials described in the article provide grounds for considering the results as a screening model for eating disorder, which may be proposed for use in psycho-educational work with adolescents.

Key words: adolescence, eating disorders, anorexia, bulimia, diet, depression, anxiety, perfectionism, self-esteem.

\section{Вступ}

Сьогодні розлади харчової поведінки (далі - РХП) є захворюванням, що відчутно знижує якість життя людей у суспільстві, а за несприятливого перебігу може призвести до летальних наслідків.

Згідно з даними британського Національного центру співпраці з питань психічного здоров'я, у 2004 р. приблизно 1 з 250 жінок та 1 із 2000 чоловіків страждали на нерво- 
ву анорексію, зазвичай, у підлітковому чи молодому віці (British Psychological Society, 2004). Приблизно в п’ять разів більше осіб страждали від нервової булімії. Станом на 2013 р., за даними статистики Американської психологічної асоціації, в розвинених країнах на розлади харчової поведінки страждали близько 1,6\% жінок і 0,8\% чоловіків (American Psychiatry Association, 2013). Відповідно до отриманих даних, анорексія та булімія зустрічаються майже в десять разів частіше у жінок, ніж у чоловіків. Дані Американської психологічної асоціації також указують, що маніфестація проявів згаданих порушень починається у пізньому дитинстві або в ранньому дорослому віці. Міжнародний Інститут оцінки показників здоров' я (IHME, 2015) оцінює кількість людей, хворих на нервову анорексію, приблизно в 2,9 млн осіб, а на нервову булімію - 3,6 млн станом на 2015 р.

Дані Національного інституту психічного здоров'я CШA (NIMH, 2015) демонструють інформацію про найбільшу поширеність розладів харчової поведінки серед осіб підліткового віку. Загальна поширеність розладів харчової поведінки серед підлітків становить 2,7\% . Водночас ці цифри коливаються від 3,8\% серед дівчат підліткового віку до $1,5 \%$ серед представників чоловічої статі. Також результати свідчать про зростання поширеності й тяжкості розладів харчової поведінки з віком.

Розлади харчової поведінки є поширеним явищем серед осіб підліткового віку в Україні (незважаючи на відсутність достовірної статистики щодо їх поширеності), проте дослідження цієї проблеми більш висвітлено у публікаціях закордонних фахівців.

Так, дослідник Frédérique Smink із колегами (Smink, van Hoeken, Oldehinkel \& Hoek, 2014) досліджували поширеність і важкість розладів харчової поведінки серед підлітків відповідно до оновлених діагностичних критеріїв DSM-5 (частина програми TRAILS: Tracking Adolescents' Individual Lives Survey, $n=2230$ ). Опитавши підлітків із 
групи ризику (n=312), учені визначили, що найпоширенішими, згідно з DSM-5, діагнозами розладів харчової поведінки у підлітків є анорексія та компульсивне переїдання. Дослідження розладів харчової поведінки в поліетнічних районах міст Великої Британії ( $\mathrm{n}=1698)$ виявило, що немає жодних етнічних відмінностей у поширеності харчових розладів (Solmi, Hotopf, Hatch, Treasure \& Micali, 2015). Додатково автори згаданого дослідження зазначили, що розлад «очистки», який не є окремим діагнозом у DSM-5, має велику коморбідність із виявленими харчовими розладами.

Актуальність обраної теми можна пояснити тим, що XX століття стало століттям ідеальних критеріїв не лише для жінок, але й для чоловіків. На думку вітчизняних дослідників (Скрипченко, Долинська, Огороднійчук \& Булах, 2001: 267-271), у підлітковому віці виявляється специфічна соціальна активність щодо засвоєння соціальних норм, цінностей і поведінки, притаманної для дорослого віку. Підліток намагається долучитися до життя та діяльності дорослих через наслідування. Саме тому спершу він чи вона переймає те, що доступне для нього: зовнішній вигляд і манеру поведінки. Новий ідеал краси змушує робити значні зусилля, аби відповідати цим стандартам, i, як зазначено у багатьох публікаціях, найпоширеніший спосіб домогтися ідеалу - схуднути за допомогою дієти. Водночас використання непризначених лікарем дієт із корекційною, лікувальною чи профілактичною метою мають високі ризики для здоров'я, що можуть перерости у розлади харчової поведінки.

Як зазначила Л. М. Абсалямова (Абсалямова, 2014), терміном «харчова поведінка» часто позначають сукупність дій і активностей, які здійснює особа у процесі харчування, в поєднанні з якісними та кількісними характеристиками й змінами раціону харчування. Авторка зауважує, що особливості харчової поведінки впливають на формування «Я-концепції», зокрема пї фізичної складової. Ука- 
зуючи на зв'язок між фізичною складовою образу власного «Я» та когнітивним й емоційним розвитком особистості, дослідниця акцентує увагу на впливі цього зв'язку опосередковано через систему харчування на особливості прояву особистісних рис і на більшість психічних процесів, зокрема й на самосвідомість. Останне, на нашу думку, є важливим аспектом під час дослідження питання схильностей до розладів харчової поведінки серед підлітків. Схожу ідейну думку ми знайшли у статті А. Є. Нижник (Нижник, 2013), у якій під терміном «харчова поведінка» описується ціннісне ставлення до процесу харчування та певний стереотип споживання їжі як у звичайних для особи умовах, так і у стресових умовах. Водночас важливим аспектом цього поняття є поведінка, орієнтована на формування образу власного тіла, й пов' язані з ним індивідуальні переконання, звички, емоції та форми поведінки щодо режиму харчування.

Mark L. Norris i колеги (Norris, et al., 2013) поставили за мету оцінити та порівняти клінічні характеристики пацієнтів зі стратегією уникаючої / обмежувальної поведінки прийому їжі з пацієнтами, які страждають на нервову анорексію. Дослідники використали ретроспективний огляд пацієнтів підліткового віку з розладами харчової поведінки, що охопив період між 2000 і 2011 роками. За даними дослідження вказано, що пацієнти з уникаючою поведінковою стратегією чи стратегією обмеження вживання їжі були молодші, ніж пацієнти з нервовою анорексією. Зазначено, що найбільша ймовірність використання подібних стратегій спостерігалася у віці до 12 років, особливо серед осіб чоловічої статі. Загальні моделі харчової поведінки і симптоми у групі з уникаючою та обмежувальною стратегіями включали уникнення їжі (голодування або жорстку дієту з мінімальними обсягами їжі), психогенну втрату апетиту, болі у животі та персистуючий страх блювання. Через високий рівень коморбідних діагнозів щодо проблем психічного та фізичного здоров'я одній третині пацієнтів 3 уникаючою / обмежувальною стратегією харчової поведін- 
ки була рекомендована шпиталізація за медичними показаннями (Norris, et al., 2013).

Водночас із бажанням досягти певного «ідеалу краси й прийняття» відбувається фізіологічна перебудова тіла, яку визначають як один з аспектів, що впливає на неприйняття образу «тілесного-Я» у підлітків. М. В. Савчин і Л. П. Василенко (Савчин \& Василенко, 2006: 208) зазначають, що у цей віковий період велику увагу приділяють фізичному образу «Я», що у свідомості підлітка є природним і надзвичайно значним, хоч і тимчасовим. Індивідуальні особливості, зокрема генетика, темперамент, сімейні чинники, фактори спільноти та суспільні чинники, можуть впливати на виникнення проблем, пов'язаних із вагою та невдоволенням станом власного тіла. І. С. Булах (Булах, 2001: 267-271) відносить порушення оцінки образу фізичного «Я» та ідентичності до основних симптомів кризи підліт-

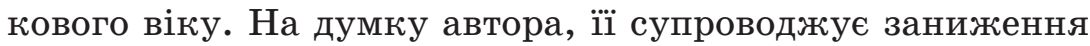
самооцінки, обумовлене переживаннями щодо надуманих недоліків образу фізичного «Я» та порівнянням себе з однолітками. Доповнюючи вищезгадане, Л. М. Абсалямова (Абсалямова, 2017) указує, що на цілісність сприйняття i прийняття власного тіла впливають чотири компоненти: загальне задоволення тілом, емоційна реакція на зміни тіла, знання та переконання про своє тіло й поведінка, пов'язана з відчуттями та виглядом власного тіла. Останній аспект включає типові прояви та вибір того, як людина одягається, як поводиться, шукає чи уникає ситуацій, у яких необхідно демонструвати тіло.

Підтвердження цьому ми знаходимо у низці публікацій, зокрема дослідники Paul Rohde, Eric Stice та C. Nathan Marti (Rohde, Stice \& Marti, 2014) виявили чинники, що збільшують ризик виникнення розладів харчової поведінки. Дані проспективного дослідження охопили 496 громад, у яких проживали підлітки жіночої статі (середній вік учасниць спостереження $\mathrm{M}=13,5$ року, $\mathrm{SD}=0,7$ на вихідному рівні). Учасники пройшли вісім щорічних 
оцінювань потенційних чинників ризиків і скринінгів розладів харчової поведінки від раннього підліткового віку до юності. Три змінні показали позитивні лінійні збільшення: сприймання «тиску бути худим/-ою», інтерналізація ідеалу, основним компонентом якого є «бути худим/-ою», і незадоволеність власним тілом. Підвищення незадоволеності власним тілом, зміни у дієті та негативна емоційність у віці 13-16 років передбачали формування розладів харчової поведінки відповідно до DSM-5 у перспективі наступних чотирьох років після кожного оцінювання, прогнозований вплив інших чинників ризику загалом обмежувався віком до 14 років. Зміни індексу маси тіла не вказували на прогноз розладів харчової поведінки в будь-якому віці. Ці результати підкреслюють необхідність ефективних програм профілактики розладів харчової поведінки для дівчат у ранньому підлітковому віці (Rohde, Stice \& Marti, 2014).

Дослідники Pamela K. Keel i K. Jean Forney (Keel \& Forney, 2013) зазначають, що епідеміологічні, міжкультурні та поздовжні дослідження підкреслюють важливість ідеалізації худорлявості та проблеми ваги як психосоціальних чинників ризику виникнення розладів харчової поведінки. Особистісні чинники, як-от негативна емоційність і максималізм, сприяють розвитку розладів харчової поведінки, але можуть зробити це побічно завдяки збільшенню чутливості до засвоєння ідеалу худорлявості або через вплив на вибір експертного середовища. Індивідуальні відмінності психологічних чинників ризику серед однолітків впливають на стосунки у соціальному середовищі й, відповідно, соціальне середовище формує психологічні чинники ризику. Саме тому в підлітковому віці контекст «середовища однолітків» може бути основною можливістю для інтервенцій. Pamela K. Keel i K. Jean Forney (Keel \& Forney, 2013) стверджують, що заходи із залученням ровесників, які кидають виклик засвоєнню ідеалу худорлявості, можуть захистити від розвитку патологій харчової поведінки. 
У багатьох англомовних статтях дієту та дієтичне харчування не визначають причиною розладів харчової поведінки, проте вона часто є їхнім попередником. У одному масштабному дослідженні дієту визначено найважливішим предиктором розвитку розладів харчової поведінки серед вікової групи 14-15 років (Golden, Schneider \& Wood, 2016). Результати згаданого дослідження показали, що серед підлітків, які дотримувалися дієти, у 5 разів частіше розвивалися розлади харчової поведінки, а серед тих, хто практикував суттєві обмеження у харчуванні, у 18 разів. Національна асоціація розладів харчової поведінки (Тhе National Eating Disorders Association), опираючись на дослідження C. M. Shisslak i M. Crago (Shisslak \& Crago, 1995), повідомляє, що $35 \%$ «нормальних дієт» прогресують до патологічних, і в 20-25\% випадків їх дотримання супроводжувалось розвитком розладів харчової поведінки. Дієта у таких випадках дає відчуття контролю під час підрахунку калорій і жирових грамів, що суттєво знижує їх вагу. Проте фокусування на дієті та схудненні може розглядатися як утеча від справжніх емоцій і проблем, які маскуються за цими ритуалами. Jacquelyn Ekern (Ekern, 2012) посилається на дослідження сімей із розладами харчової поведінки, опубліковане в журналі Американської дієтологічної асоціації в 1992 р. Було вказано, що приблизно у 82\% випадків дотримання дієт без рекомендацій фахівців було помічено на рівні усієї родини та у рамках сімейних традицій.

Мета статті - виявити вплив дотримання дієти поза медичними показаннями на схильність формування розладів харчової поведінки серед підлітків.

\section{Завдання статті}

Завданнями дослідження було визначено: проаналізувати сучасні погляди, висвітлені у науковій літературі, на схильність формування розладів харчової поведінки серед підлітків; дослідити вплив дотримання дієти, не призначеної лікарем із метою корекції, лікування чи профілакти- 
ки, на схильність формування розладів харчової поведінки серед підлітків; сформувати концептуальну модель схильності до формування розладів харчової поведінки з метою подальшої розробки рекомендацій щодо їх попередження чи зменшення негативного впливу.

\section{Методи та методики дослідження}

Пошук попередніх досліджень, пов'язаних із темою статті, ми здійснювали через PubMed, Medline, Web-ofScience, BIOSIS, Cochrane library and Research Gate. Для огляду актуальних досліджень ми використали статті, опубліковані не пізніше як 10 років тому, а суб'єктами дослідження були підлітки. Пошук здійснювався за такими ключовими словами: «розлади харчової поведінки»; «нервова анорексія»; «булімія»; «орторексія»; «дієтичне харчування»; «adolescent»; "eating disorder»; «anorexia», «bulimia».

Із метою розв'язання завдань дослідження нами була сформована базова брошура, яка містила твердження, що стали основними критеріями розподілу контрольної та досліджуваної груп. Брошура була розповсюджена серед підлітків віком 12-14 років, які навчаються у школах м. Тернополя та м. Львова. Це дослідження здійснювалося у співпраці з психологами цих закладів і Тернопільським міським центром соціальних служб для сім’ї, дітей та молоді.

Анкета містила такі твердження:

1. Я дуже хочу схуднути.

2. Я харчуюся дієтичними продуктами.

3. Я утримуюсь від продуктів харчування, які містять цукор.

4. Зазвичай я читаю рецепти, книги з кулінарії, списки калорій, книги про дієти і фізичні вправи для схуднення.

5. Я регулярно роблю одну або кілька речей з їжею: ділю її на дрібні частинки, їм спеціальним способом та у певний час, їм зі спеціального мірного посуду, викидаю, коли ніхто не бачить, або віддаю собаці / кішці, ховаю їжу. 
6. Я настільки стурбований тим, як виглядає моє тіло, що просто зобов'язаний дотримуватися дієти.

7. Наразі я дотримуюся дієти.

8. Дієта, якої я дотримуюся, призначена лікарем або дієтологом.

Позитивні відповіді на твердження 1-6 стали критерієм «A» для відбору до участі у дослідженні. Позитивна відповідь на твердження № 7 стала критерієм «В», а негативну відповідь на твердження № 8 було використано як критерій «С» для відбору до експериментальної групи.

На початку дослідження ми отримали 347 анкет. Із них було відсіяно 116 анкет через невідповідність критерію «А». 108 учасників увійшли до контрольної групи через відповідність критерію «A» та відсутність критеріїв «B» $\mathrm{i}$ «С». Із наступних 123 анкет було відсіяно 35 анкет, які відповідали критерію «В», але не відповідали критерію «С», оскільки респонденти дотримувалися дієт згідно з призначенням лікаря. До експериментальної групи увійшло 88 респондентів. Для подальшого дослідження ми не розподіляли респондентів відповідно до статі та віку.

Обраним учасникам було запропоновано діагностичну брошуру пілотного дослідження, що включала Eating Disorders Impairment Questionnaire - 3 (Garner, 2004) та скринінгову шкалу на виявлення тривоги і депресії HADS (Zigmond \& Snaith, 1983).

Методика EDI-3 була надана на партнерських засадах компанією ОС України, яка є асоційованим членом Свропейської групи видавців тестів (ETPG). Опитувальник EDI-3 складається з 91 твердження, розділеного на 12 основних шкал і 6 комплексних показників, отриманих додаванням Т-балів двох або більше шкал. Респонденти повинні оцінити за 6-бальною шкалою частоту певних дій, думок або почуттів. Відповіді групуються в 12 шкал, виокремлених під час статистичного аналізу. Три з головних шкал помічені як шкали ризику розвитку розладів харчової поведінки: прагнення до стрункості (DT), булімія (B), 
незадоволеність тілом (BD). Дослідження виявили, що високі показники за цими шкалами свідчать про підвищений ризик виникнення розладів харчової поведінки. Дев'ять інших шкал оцінюють психологічні конструкти, які є концептуально близькими до виникнення та перебігу розладів харчової поведінки.

У зв'язку з конфіденційністю всі анкети заповнювалися анонімно й опісля були покодовані. Час тестування для трьох анкет мав тривати не більше 30 хвилин, проте, як показав досвід, його тривалість становила 1 годину.

У період організації дослідження ми зіткнулися з низкою проблем: організаційними проблемами, пов'язаними з тим, що не всі школи були зацікавлені у проведенні анкетування серед їх учнів; нерозумінням деяких запитань із методики EDI-3, які безпосередньо стосувалися прийняття свого тіла чи розуміння емоційних станів.

\section{Результати та дискусії}

Попередній порівняльний аналіз результатів за методикою EDI-3 згідно з критерієм Mann-Whitney U-test для двох вибірок показав статистично значущу відмінність $(\mathrm{p}<\mathbf{0 , 0 1 )}$ між контрольною та експериментальною групами за такими показниками з перевагою їх у групі підлітків, які дотримуються дієти без призначення лікаря: «Прагнення до стрункості», «Невдоволеність тілом», «Низька самооцінка», «Страх дозрівання», «Міжособистісне відчуження», «Перфекціонізм» і «Булімія» .

Отримані показники значущої відмінності за шкалою «Прагнення до стрункості» (DT, p = 0,0001) свідчать, що для респондентів експериментальної групи характерне більше бажання бути стрункішими, хвилювання щодо дотримання дієт, моніторинг змін ваги та нав'язлива тривога щодо підтвердження негативних очікувань, що є скринінговою ознакою для РХП. Бажання бути стрункішим може відображати інтерналізацію сильних соціальних вказівок через засоби масової інформації, які заохочують 
молодих дівчат і хлопців дотримуватися дієти для досягнення стандартів форми тіла та ваги (Маслюк, 2011; Шанкенберг, 2017: 28-29). Як наслідок, ми можемо спостерігати, як підлітки, незадоволені формами власного тіла, почуваються винними через уживання навіть нормальної кількості їжі. Підтвердженням цього також є високий показник «Незадоволеності тілом» (BD, p = 0,006) серед учасників експериментальної групи. Отримані результати засвідчують, що підлітки можуть приділяти надмірну та непродуктивну увагу ділянкам тіла, які найбільше змінюються внаслідок психосексуального розвитку. Підлітки намагаються змінити «проблемні місця» за допомогою фізичних навантажень та обмеження в їжі.

Водночас у групі підлітків, які дотримуються дієти без призначення лікаря, виявилися високі та статистично значущі показники «Низької самоцінки» (LSE, p = 0,0062). Занижена самооцінка, на думку Л. Вайтгед (Вайтгед, 2014: 36-38), впливає на контроль над харчуванням, який дає змогу підвищити самоповагу. Тому, розвиваючись за варіантом непродуктивного копінгу, низька самооцінка підштовхує підлітка досягати поставлених цілей посиленням вимог до себе. Водночас невдачі на цьому шляху завдають ще більшого удару самооцінці, формуючи думки, що людина нічого не здатна змінити у своєму житті (Waller, et al., 2007: 110-113).

Потрібно підкреслити, що, на нашу думку, підлітки, які намагаються, проте не досягають стандартів, мають виражені почуття особистісної нестабільності та труднощі з самоповагою. Високі результати за шкалою «Страху дозрівання» (MF, p = 0,000173) в експериментальній групі можуть свідчити про бажання підлітків повернутися до безпечного дитинства. Так, прагнення схуднути мотивоване страхами, пов'язаними з конфліктом дорослішання. Одним із результатів схуднення є бажання повернення до препубертатної зовнішності, що дає можливість відчути певну стабільність і повертає відчуття самоповаги через 
самоконтроль. Крім того, підлітки відзначають, що сприймають себе молодшими після значної втрати ваги (подібну тенденцію суб'єктивного сприйняття ми можемо спостерігати й серед дорослих, які контролюють власну вагу).

Поруч із зазначеними вище свідченнями розчарування та невпевненості у собі, зумовленими неприйняттям своєї зовнішності й тіла, спостерігаємо високі показники за шкалою «Міжособистісного відчуження» (IA, p = 0,000103). Дистанціювання, відчуження і відсутність довірливих взаємовідносин часто зумовлює ізоляцію та скутість у спілкуванні з іншими (Виттхен, 2006: 226-228). Водночас, ми думаємо, що підліток, який має друзів, може почувати себе у стосунках, як у пастці. Йому може бути важко отримати розуміння та відчуття власного прийняття у колі друзів, через недосягнення суб’єктивного внутрішнього критерію «бути підходящим».

Підсилення особистісних рис, спрямованих на дотримання непродуктивних стратегій, знайшло своє відображення у високих результатах за шкалою «Перфекціонізму» $(\mathrm{P}, \mathrm{p}=0,00004)$. Ми погоджуємося з думкою дослідників, що перфекціонізм як особистісна риса доповнює згадані вище проблеми й може бути визначений як ключова риса у розвитку та закріпленні РХП (Fairburn, 2008: 200; Plooy, 2017: 255-256). Ми розглядаємо перфекціонізм як рису, що лежить в основі невпинних зусиль, спрямованих на контроль харчування та ваги, а також нереалістичних прагнень в інших галузях. Підліток, усвідомлюючи свою невдачу в досягненні жорстких особистих стандартів у харчуванні, ще рішучіше намагається досягти поставлених цілей, формуючи компульсивний характер реалізації преморбідних рис (Waller, et al., 2007: 110-113; Вайтгед, 2014: 36-38).

Одна з головних шкал, що позначена як шкала ризику розвитку розладів харчової поведінки - «Булімія» (В, $\mathrm{p}=0,000348)$, статистично вища за такий самий показник контрольної групи. Високий бал за цією шкалою для 
експериментальної групи може свідчити про періоди компульсивного переїдання. Подібні періоди втрати контролю над харчуванням можуть бути свідченням зриву стратегій, які підліток використовує як спосіб впливу на інші сфери життя. Компульсивне переїдання, з одного боку, є наслідком суворих і невідповідних дієт, але й може виникати як реакція на емоційні страждання - самотність, депресію, гнів, страх. Ці напади можуть на короткий час поліпшувати самопочуття, однак після цього настає гостре почуття сорому та провини, огиди, а також страх набрати вагу. Своєю чергою, це може спровокувати нові спроби або посилення попередніх вимог щодо обмеження вживання їжі чи блювання з метою втрати ваги (Вайтгед, 2014: 28-30).

Використовуючи програму Statistica 8, нами було проведено дослідження кореляційного зв'язку між шкалами методик EDI-3 та HADS за допомогою критерію Спірмана для неузгодженого з нормальним розподілом. Отримані результати демонструють нам багато високих кореляційних зв' язків, які ми описали й інтерпретували.

1. «Прагнення до стрункості» (DT) статистично корелює 3 «Незадоволеністю тілом» (BD) (DT - BD: $r<0,69$, $\mathrm{p}<0,01)$ i «Низькою самооцінкою» (LSE) (DT - LSE: $\mathrm{r}<0,54, \mathrm{p}<0,01$; BD - LSE: $\mathrm{r}<0,55, \mathrm{p}<0,01)$. Такий високий зв'язок між шкалами може свідчити, що рівень самооцінки залежить від того, як підліток сприймає власне тіло та компенсує власну стурбованість через прагнення виглядати стрункішим (формування правил і обмежень щодо стрункості власного тіла). Їх дотримання посилює позитивну самооцінку, а зрив правил / обмежень знижує iii. Ураховуючи отримані дані, ми припустили, що поєднання незадоволеності певними ділянками тіла (або його стрункістю загадом) і низької самооцінки є комбінованим чинником ризику, який відповідає за появу та закріплення надмірних поведінкових проявів, спрямованих на контроль ваги, які призводять до формування РХП у вразливих осіб. 
2. Позитивний показник кореляції між «Низькою самооцінкою» (LSE), «Незадоволеністю тілом» (BD) і «Тривогою» шкали $\mathrm{HADS}(\mathrm{AN})(\mathrm{LSE}-\mathrm{AN}: \mathrm{r}<0,45, \mathrm{p}<0,01$; $\mathrm{BD}-\mathrm{AN}: \mathrm{r}<0,40, \mathrm{p}<0,01)$ дав нам підстави вважати, що підліток відчуває посилену тривогу щодо вигляду власного тіла. Особливості підліткового сприйняття та непродуктивні думки, якими він чи вона описує власні відчуття й хвилювання, у сукупності з низьким рівнем самооцінки посилюють використання неефективних стратегій опанування тривоги через надмірний контроль.

Водночас, коли тривога через низку різних причин стає неконтрольованою, це призводить до зриву дотримання режиму харчування та закріпленої харчової поведінки, що безпосередньо підсилює низьку самооцінку (Вайтгед, 2014: 28-30). Підтвердження цього ми вбачаємо у наявності прямої кореляції між шкалами «Булімії» та «Тривоги» $(\mathrm{r}<0,50, \mathrm{p}<0,01)$; «Булімії» та «Незадоволеності тілом» $(\mathrm{r}<0,48, \mathrm{p}<0,01)$; «Булімії» та «Прагнення до стрункості» $(\mathrm{r}<0,41, \mathrm{p}<0,01)$. На нашу думку, це є свідченням тенденції до нападів неконтрольованого переїдання у відповідь на емоційну фрустрацію і, як стверджує М. Герлінхофф (Виттхен, 2006: 226-228), може свідчити про виражений психологічний дистрес. Як наслідок, неможливість досягти емоційної стабільності та лише часткове полегшення через зрив дієти і вживання «великої» кількості їжі посилює відчуття провини та фрустрації. У подальшому негативний емоційний стан провокує звернення до стратегій очисної поведінки з метою його зменшення та повернення до відносного стану контролю й стабільності (Waller, et al., 2007: 110-113; Fairburn, 2008: 200).

Під час дослідження також виявлено пряму кореляцію між шкалами «Міжособистісне відчуження» та «Депресія» ( $<<0,46, \mathrm{p}<0,01)$; «Незадоволеність тілом» $\mathrm{i}$ «Депресія» $(\mathrm{r}<0,42, \mathrm{p}<0,01)$ й між «Незадоволеністю тілом» $\mathrm{i}$ «Міжособистісним відчуженням» $(\mathrm{r}<0,44, \mathrm{p}<0,01)$. На нашу думку, такі зв'язки можуть вказувати на те, що через від- 
Збіршик наукових праць К-ПНу імені Івана Отієнка, Інституту психології імені Г. С. Костюка НАПН України

сутність дружніх стосунків прояви депресії, пов'язані 3 незадоволенням власним тілом, можуть посилюватися. Отримані показники вказують на формування певного «зачарованого» кола, у якому підліток зі схильністю до РХП відчуває хвилювання, еквівалентні симптомам депресії. Своєю чергою, скарги на втрату задоволення чи неможливість його досягнення, зниження бажання продовжувати діяльність чи підтримувати стосунки підсилюються через недосягнення «еталону краси», а відсутність підтримки через самоізоляцію (характерну для депресивних станів) залишає його з цією проблемою сам на сам. Аналізуючи отримані результати, ми прийшли до думки, що підліток, який мислить про себе як про такого, хто не може відповідати власним стандартам, має труднощі у встановленні чи підтриманні дружніх стосунків з однолітками. А без наявності підтримки та довірливих стосунків зростає незадоволеність виглядом власного тіла й погіршується самооцінка (LSE - IA: $\mathrm{r}<0,54, \mathrm{p}<0,01)$.

\section{Висновки}

За результатами пілотного дослідження виявлено, що для підліткового віку характерно хвилювання щодо власного зовнішнього вигляду та незадоволеність ним, що підтримується низькою самооцінкою. На противагу підліткам, які не дотримуються дієти задля підтримання власного стандарту «краси», однолітки, які використовують дієти, не призначені лікарем з метою корекції, лікування чи профілактики, мають багато показників, які пов'язані між собою та підтримують схильність до розвитку РХП.

Ядро моделі схильності до РХП складають 5 аспектів, ключовими серед яких є незадоволеність власним тілом i низька самооцінка. Підліток, незадоволений власним тілом, починає оцінювати свої форми та вагу, які, на його думку, мають безліч недоліків. Певні частини тіла можуть демонструвати ознаки статевого дозрівання та поступовий перехід до зрілості, до якої підліток може бути неготовим. 
Тому низька самооцінка загострюе фокусування на проблемних ділянках тіла. Ці показники підтримують одне одного та демонструють нам замкнене коло, де вплив здійснюється не однобічно.

Також у ядро моделі входять прагнення до стрункості, тривога, що відчувається щодо цього, та схильність до міжособистісного відчуження. Важливим аспектом є розуміння, що підвищення тривоги пов'язане з тим, що підліток не може одразу вплинути на власне тіло, щоб воно відповідало його стандарту. Своєю чергою, це підсилює прагнення до стрункості та, як одна з поширених стратегій, використовується самовільно призначена дієта з обмеженим режимом харчування і кількості їжі. Варто звернути увагу, що такий спосіб життя веде до міжособистісного відчуження, коли підліток починає дистанціюватися від друзів, які можуть не підтримувати його поведінку щодо обмеження їжі чи виконання надмірних фізичних вправ. Ці показники мають високий зв'язок із центральними показниками, які, на нашу думку, формують зміст розладів харчової поведінки.

Ми вважаємо, що депресія і тривожна булімія можуть бути самостійними тригерами для дистресу компонентів ядра схильності. Водночас показник булімії може бути частиною клінічної картини або коморбідністю, що виникає внаслідок підвищеної тривоги через незадоволеність власним тілом. Одним із наслідків цього може бути підсилення підліткової депресії.

Модифікуючими чинниками, що підтримують розвиток РХП, є страх дозрівання та перфекціонізм. Перебудова тіла лякає підлітка, адже це ставить перед ним нові виклики. Збільшується відповідальність і зменшується його безтурботність, яка була присутня в дитинстві. Усе це, на нашу думку, посилює страх дозрівання. В уявленні підлітка зміни у житті можуть підтримувати когнітивне викривлення, що поступово виходить з-під контролю, тому тіло стає тим об'єктом, на який він має вплив. Перфекціонізм бере гору, 
і підліток починає контролювати свій раціон харчування за допомогою дієти, а також своє тіло, здійснюючи фізичні навантаження. Усе це дає відчуття полегшеності на якийсь час, адже зриви в харчуванні ще більше загострюють відчуття незадоволеності тілом і вищеперераховані психологічні аспекти й стратегії харчової поведінки.

Водночас потрібно зазначити, що самостійне дотримання жорсткої дієти без консультації з фахівцем також може бути проявом міжособистісного відчуження. Хибне уявлення, що спеціаліст може не зрозуміти проблем підлітка або проігнорувати їх, підкріплюється низькою самооцінкою й недовірою до дорослих. Останнє ми розглядаємо як один з аспектів підліткового віку.

У майбутньому ми плануємо здійснити апробацію запропонованої нами скринінгової моделі, провівши скринінгові дослідження учасників експериментальної групи на ознаки РХП відповідно до критеріїв DSM-5 через півроку та рік.

\section{Література}

Абсалямова Л. М. Образ тіла як психологічний чинник порушень харчової поведінки. Вісник ХНПУ імені Г. С. Сковороди. Психологія. Харків : ХНПУ, 2017. Вип. 56. С. 1-9. DOI http://doi.org/10.5281/ zenodo.888328.

Абсалямова Л. М. Розлади та порушення харчової поведінки особистості. Проблели сучасної психологї̈: Збірник наукових праць Кал'янець-Подільського національного університету імені Івана Огієнка, Інституту психології імені Г.С. Костюка НАПН України / За ред. С. Д. Максименка, Л. А. Онуфрієвої. Кам'янець-Подільський : Аксіома, 2014. Вип. 25. С. 19-33.

Булах I. С. Психологія особистості підлітка. Вікова та педагогічна психологія: навч. посібник / О. В. Скрипченко, Л. В. Долинська, 3. В. Огордійчук та ін. Київ : Просвіта, 2001. 416 с.

Вайтгед Л. Подолати розлад харчової поведінки / пер. з англ. Ігор Грицюк; наук. ред. Катерина Явна. (Серія «Сам собі психотерапевт»). Львів : Видавництво Українського Католицького Університету; Свічадо, 2014. 112 с.

Виттхен Г.-У. Энциклопедия психологического здоровья. Москва : Алтейа, 2006. 524 c. 
Маслюк А. М. Нервова анорексія як наслідок соціалізації особистості. Проблели сучасної психології: Збірник наукових праць Кам'янецьПодільського національного університету ілені Івана Огієнка, Інституту психологї ілені Г. С. Костюка НАПН України / За ред. С.Д. Максиленка, Л.А. Онуфрієвої. Кам'янець-Подільський : Аксіома, 2011. Вип. 11. С. 454-463.

Нижник А. Є. Харчова поведінка молоді як предмет психологічного дослідження. Наукові записки. Серія: Психологія та педагогіка. Острог : Вид-во Національного університету «Острозька академія», 2013. Вип. 22. С. 136-141.

Савчин М. В. Вікова психологія: навч. посіб. Київ : Академвидав, 2006. $360 \mathrm{c.}$

Шнаккенберг Н. Мнимые тела, подлинные сущности: Преодоление конфликтов идентичности с внешностью и возвращение к подлинному Я [пер. с англ.]. Калининград : Phoca Books, 2017. 376 с.

American Psychiatry Association (2013). Diagnostic and Statistical Manual of Mental Disorders (5thed.). Arlington : American Psychiatric Publishing.

British Psychological Society \& The Royal College of Psychiatrists (2004). Eating Disorders. Core interventions in the treatment on core interventions in primary and management of anorexia and secondary carenervosa, bulimia nervosa and related eating disorders.

Global Burden of Disease (2017). Disease and Injury Incidence and Prevalence Collaborators. Global, regional, and national incidence, prevalence, and years lived with disability for 310 diseases and injuries, 1990-2015: a systematic analysis for the Global Burden of Disease Study 2015. Lancet 2017; 389. DOI 10.1016/S0140-6736(16)32606-X.

Ekern, J. (2012). Dieting and Eating Disorders. Retrieved from https:// www.eatingdisorderhope.com/treatment-for-eating-disorders/special-issues/dieting.

Fairburn, C. G. (2008). Cognitive behavior therapy and eating disorders. New York : Guilford Press.

Golden, N. H., Schneider, M., \& Wood, C. (2016). Preventing Obesity and Eating Disorders in Adolescents. Pediatrics, 138 (3). DOI 10.1542/ peds.2016-1649.

Keel, P. K., \& Forney, K. J. (2013). Psychosocial risk factors for eating disorders. International Journal of Eating Disorder, 46 (5). DOI 10.1002/eat.22094.

National Institute of Mental Health (2017). Retrieved from https://www. nimh.nih.gov/health/statistics/eating-disorders.shtml.

Norris, M. L., Robinson, A., Obeid, N., Harrison, M., Spettigue, W., \& Henderson, K. (2013). Exploring avoidant / restrictive food intake disorder in eating disordered patients: A descriptive study. International Journal of Eating Disorder, 47 (5). DOI 10.1002/eat.22217. 
Plooy, G. N. (2017). Candidate Declaration «Perfectionism: An exploratory analysis of treatment resistant eating disorder clients during intervention». Retrieved from http://uir.unisa.ac.za/bitstream/handle/10500/23184/thesis_walters-du\%20plooy_g.pdf.

Rohde, P., Stice, E., \& Marti, C. N. (2014). Development and predictive effects of eating disorder risk factors during adolescence: Implications for prevention efforts. International Journal of Eating Disorder, 48 (2). DOI 10.1002/eat.22270.

Shisslak, C. M., Crago, M., \& Estes, L. S. (1995). The spectrum of eating disturbances. International Journal of Eating Disorders, 18 (3), 209-219.

Smink, F. R. E., van Hoeken, D., Oldehinkel, A. J., \& Hoek H. W. (2014). Prevalence and severity of DSM-5 eating disorders in a community cohort of adolescents. International Journal of Eating Disorder, 46 (6). DOI 10.1002/eat.22316.

Solmi, F., Hotopf, M., Hatch, S. L., Treasure, J., \& Micali, N. (2015). Eating disorders in a multi-ethnic inner-city UK sample: prevalence, comorbidity and service use. Social Psychiatry and Psychiatric Epidemiology, 51 (3). DOI 10.1007/s00127-015-1146-7.

Waller, G., Cordery, H., Corstorphine, E., Hinrichsen, H., Lawson, R., Mountford, V., \& Russell, K. (2007). Cognitive behavioural therapy for the eating disorders: a comprehensive treatment guide. Cambridge University Press. DOI 10.1017/CBO9781139644204.

\section{References}

Absaliamova, L. M. (2017). Obraz tila yak psykholohichnyi chynnyk porushen kharchovoi povedinky [Body image as a psychological factor of behavioral disorders]. Visnyk HNPU imeni H. S. Skovorody. Psykholohiia - Newsletter of KNPU named after G. S. Skovoroda, 56, 001-009 [in Ukrainian].

Absaliamova, L. M. (2014). Rozlady ta porushennia kharchovoi povedinky osobystosti [Disorders and disfunctions of an individual's eating behavior]. Problemy suchasnoi psykholohii: Zbirnyk naukovykh prats Kamianets-Podilskoho natsionalnoho universytetu imeni Ivana Ohiienka, Instytutu psykholohii imeni H. S. Kostiuka NAPN Ukrainy Problems of modern psychology: Collection of research papers of $\mathrm{Ka}$ mianets-Podilskyi Ivan Ohienko National University, G. S. Kostiuk Institute of Psychology at the National Academy of Pedagogical Science of Ukraine, 25, 19-33 [in Ukrainian].

Bulakh, I. S. (2001). Psykholohiia osobystosti pidlitka [Psychology of the personality of the adolescent]. Vikova ta pedahohichna psykholohiia - Age-related and Pedagogical Psychology. Kyiv : Prosvita [in Ukrainian]. 
Whitehead, L. (2014). Podolaty rozlad kharchovoi povedinky [Overcoming eating disorder] (Igor Grycjuk, Trans; Kateryna Javna, Eds). Lviv : Vydavnytstvo Ukrainskoho Katolytskoho Universytetu; Svichado [in Ukrainian].

Vytthen, G.-U. (2006). Jenciklopedija psihologicheskogo zdorov'ja [Encyclopedia of psychological health]. Moskva : Alteja [in Russian].

Masliuk, A. M. (2011). Nervova anoreksiia yak naslidok sotsializatsii osobystosti [Nervous anorexia as a consequence of the socializing of the personality]. Problemy suchasnoi psykholohii: Zbirnyk naukovyh prats Kamianets-Podilskoho natsionalnoho universytetu imeni Ivana Ohiienka, Instytutu psykholohii imeni H. S. Kostiuka NAPN Ukrainy - Problems of modern psychology: Collection of research papers of Kamianets-Podilskyi Ivan Ohienko National University, G.S. Kostiuk Institute of Psychology of NAPS of Ukraine, S. D. Maksymenko, L. A. Onufriieva (Eds ), 11, 454-463 [in Ukrainian].

Nyzhnyk, A. E. (2013). Kharchova povedinka molodi yak predmet psykholohichnoho doslidzhennia [Eating behavior of youth as a subject of psychological research]. Naukovi zapysky. Seriia: Psykholohiia ta pedahohika - Scientific notes. Series: Psychology and Pedagogy, 22, 136-140 [in Ukrainian].

Savchyn, M. V. (2006). Vikova psykholohiia [Age psychology]. Kyiv : Akademvydav [in Ukrainian].

Schnackenberg, N. (2017). Mnimye tela, podlinnye sushchnosti: Preodolenie konfliktov identichnosti s vneshnost'ju i vozvrashchenie $k$ podlinnomu Ja [False Bodies, True Selves: Moving Beyond AppearanceFocused Identity Struggles and Returning to the True Self]. (Trans.). Kaliningrad : Phoca Books [in Russian].

American Psychiatry Association (2013). Diagnostic and Statistical Manual of Mental Disorders (5thed.). Arlington : American Psychiatric Publishing.

British Psychological Society \& The Royal College of Psychiatrists (2004). Eating Disorders. Core interventions in the treatment on core interventions in primary and management of anorexia and secondary carenervosa, bulimia nervosa and related eating disorders.

Global Burden of Disease (2017). Disease and Injury Incidence and Prevalence Collaborators. Global, regional, and national incidence, prevalence, and years lived with disability for 310 diseases and injuries, 1990-2015: a systematic analysis for the Global Burden of Disease Study 2015. Lancet 2017; 389. DOI 10.1016/S0140-6736(16)32606-X.

Ekern, J. (2012). Dieting and Eating Disorders. Retrieved from https:// www.eatingdisorderhope.com/treatment-for-eating-disorders/special-issues/dieting.

Fairburn, C. G. (2008). Cognitive behavior therapy and eating disorders. New York : Guilford Press. 
Golden, N. H., Schneider, M., \& Wood, C. (2016). Preventing Obesity and Eating Disorders in Adolescents. Pediatrics, 138 (3). DOI 10.1542/ peds.2016-1649.

Keel, P. K., \& Forney, K. J. (2013). Psychosocial risk factors for eating disorders. International Journal of Eating Disorder, 46 (5). DOI 10.1002/eat.22094.

National Institute of Mental Health (2017). Retrieved from https://www. nimh.nih.gov/health/statistics/eating-disorders.shtml.

Norris, M. L., Robinson, A., Obeid, N., Harrison, M., Spettigue, W., \& Henderson, K. (2013). Exploring avoidant / restrictive food intake disorder in eating disordered patients: A descriptive study. International Journal of Eating Disorder, 47 (5). DOI 10.1002/eat.22217.

Plooy, G. N. (2017). Candidate Declaration «Perfectionism: An exploratory analysis of treatment resistant eating disorder clients during intervention». Retrieved from http://uir.unisa.ac.za/bitstream/handle/10500/23184/thesis_walters-du\%20plooy_g.pdf.

Rohde, P., Stice, E., \& Marti, C. N. (2014). Development and predictive effects of eating disorder risk factors during adolescence: Implications for prevention efforts. International Journal of Eating Disorder, 48 (2). DOI 10.1002/eat.22270.

Shisslak, C. M., Crago, M., \& Estes, L. S. (1995). The spectrum of eating disturbances. International Journal of Eating Disorders, 18 (3), 209-219.

Smink, F. R. E., van Hoeken, D., Oldehinkel, A. J., \& Hoek H. W. (2014). Prevalence and severity of DSM-5 eating disorders in a community cohort of adolescents. International Journal of Eating Disorder, 46 (6). DOI 10.1002/eat.22316.

Solmi, F., Hotopf, M., Hatch, S. L., Treasure, J., \& Micali, N. (2015). Eating disorders in a multi-ethnic inner-city UK sample: prevalence, comorbidity and service use. Social Psychiatry and Psychiatric Epidemiology, 51 (3). DOI 10.1007/s00127-015-1146-7.

Waller, G., Cordery, H., Corstorphine, E., Hinrichsen, H., Lawson, R., Mountford, V., \& Russell, K. (2007). Cognitive behavioural therapy for the eating disorders: a comprehensive treatment guide. Cambridge University Press. DOI 10.1017/CBO9781139644204.

\section{АНОТАЦІЯ}

У статmі розглянуто вплив дієти, яку використовують підлітки поза медичними показаннями, як засіб контролю за власною вагою, емоційним станом і для підтримання самооцінки.

здійснено аналіз досліджень за останні 10 років, проаналізовано й описано психосоціальні чинники схильності до формування розладів харчової поведінки серед підлітків. Із метою розв'язання поставлених 
завдань було сформовано вибірку досліджуваних: підлітки віком 12-14 років, які навчаються у школах м. Тернополя та м. Львова. На початку дослідження було отримано 347 анкет, до експериментальної групи увійшло 88. Обраним учасникам було запропоновано діагностичні матеріали, зокрема методику Eating Disorders Impairment Questionnaire - 3 та скринінгову шкалу на виявлення тривоги і депресії Hospital Anxiety and Depression Scale.

За результатами роботи описано особливості схильності до розладів харчової поведінки серед підлітків, які дотримувалися дієти поза призначеннями лікаря. Отримані дані розкривають 5 аспектів схильності, ключовими серед яких є незадоволеність власним тілом і низька самооцінка. Установлено, що низька самооцінка загострює фіксацію на проблемних ділянках тіла, посилюючи прагнення до стрункості, а непродуктивне використання жорстких дієт чи обмежень кількості їні дає відчуття контролю над емоціями та думками. Водночас указано, що тривога, яку відчувають щодо цього, впливає на схильність до міжособистісного відчуження. Зауважено, що депресивний стан і неконтрольоване переїдання можуть бути самостійними тригерами для дистресу компонентів ядра схильності, а модифікуючими чинниками, що підтримують розвиток порушень харчової поведінки, є страх дозрівання та перфекціонізм.

Описані у статmі матеріали дають підстави розглядати отримані результати як скринінгову модель схильності до розладів харчової поведінки, а на їх основі можуть бути запропоновані заходи, які доцільно використовувати для психоедукаційної роботи з підлітками.

Ключові слова: підлітковий вік, розлади харчової поведінки, анорексія, булімія, дієта, депресія, тривога, перфекціонізм, самооцінка.

Аврамчук Александр, Круи Оксана. Особенности склонности к расстройствам пищевого поведения среди подростков, которые придерживаются диеты вне показаний врача

\section{АННОТАЦИЯ}

В статье рассмотрено влияние диеты, которую используют подростки вне медицинских показаний, как средство контроля над собственным весом, эмоциональным состоянием и для поддержания самооценки.

Осуществлен анализ исследований по данной проблематике за последние 10 лет, проанализированы и описаны психосоциальные факто- 
ры предрасположенности к формированию расстройств пищевого поведения среди подростков. С целью решения поставленных задач была сорормирована выборка испытуемых: подростки в возрасте 12-14 лет 2. Тернополя и г. Львова. В начале исследования получено 347 анкет, в экспериментальную группу вошло 88 участников. Отобранным участникам было предложено диагностические материалы, которые включали методику Eating Disorders Impairment Questionnaire - 3 и скринингшкалу на выявление тревоги и депрессии Hospital Anxiety and Depression Scale.

По результатам работы было описано особенности склонности к расстройствам пищевого поведения среди подростков, которые придерживались диеты вне назначения врача. Полученные данные раскрывают 5 аспектов склонности, ключевыми из которых являются неудовлетворенность собственным телом и низкая самооценка. Было установлено, что низкая самооценка обостряет фиксацию на проблемных участках тела, усиливая стремление к стройности, а использование жестких диет или ограничений количества пищи дает ощущение контроля над эмоциями и мыслями. В то же время указано, что тревога, которую чувствуют из-за этого, влияет на склонность к межличностному отчуждению. Сделано выводы, что депрессивное состояние и неконтролируемое переедание могут быть самостоятельными триггерами для дистресса компонентов ядра склонности, а модифицирующими фракторами, которые поддерживают развитие нарушений пищевого поведения, выступают страх созревания и перфекционизм.

Описанные в статье материалы дают основания рассматривать полученные результаты как скрининговую модель склонности к расстройствам пищевого поведения, на основе которой могут быть предложены меры для психоэдукации среди подростков.

Ключевые слова: подростковый возраст, расстройства пищевого поведения, анорексия, булимия, диета, депрессия, тревога, перфекционизм, самооценка. 